Journal Universitas Muhammadiyah Gresik Engineering, Social Science, and Health International Conference (UMGESHIC)

UMGCINMATIC : $1^{\text {st }}$ Rethinking Education during Covid-19 Era: Challange and Innovation

\title{
OPTIMALIZATION OF CHITIN REACTION PROCESS CONDITIONS INTO CHITOSAN FROM SCALLOP SHELLS (PLACUNA PLACENTA)
}

\author{
Author \\ Kurnia Pratiwi Agustin ${ }^{1}$, Benny Arif Pambudiarto \\ Chemical Engineering Department, Muhammadiyah University of Gresik ${ }^{1}$, \\ Chemical Engineering Department, Muhammadiyah University of Gresik ${ }^{2}$
}

Kurniaprtwi_190606@umg.ac.id',Benny.arif@umg.ac.id²

\begin{abstract}
In 2009, the total production of Placuna placenta reached 68.27 tons in central java. The implication of that is causing a pile of waste from shell which contain $14-35 \%$ of chitin. Chitin can be further processed into chitosan, a compound that has anti-bacterial properties, following 3 processes and one of them is the deacetylation process. The process is removing the acetyl group from chitin through a heating process with the addition of base at a high concentration. The results showed that optimum process obtained at temperature $750 \mathrm{C}$ and base concentration $70 \% \mathrm{~W} / \mathrm{V}$. Similar results were obtained for these results on 3 times repetation. In further, related research will use the following optimized process conditions.
\end{abstract}

Keywords: Placuna placenta, Scallop Shells, Chitosan

\section{INTRODUCTION}

Indonesia is the third largest maritime archipelagic country in the world, which has great potential in marine resources. Two-thirds of Indonesia's territory consists of the sea and the rest are islands, with a sea area of 7,827,087 km2 with around 17,504 islands[1]. Indonesia's maritime economic potential is estimated at 7,200 trillion per year, which comes from marine products such as fish, shrimp, seaweed and types of shellfish.

The northern coast of Java, especially the Pojok Sukorejo Village, Kebomas District, Gresik Regency, East Java Province, is one of the largest scallop-producing areas. The utilization of scallops in some areas is generally only used as consumption shells so that the rest of the shells becomes waste. The reuse of scallop shell waste is still very lacking, while at this time the existence of more and more shellfish waste causes disturbance to the surrounding environment. The more waste that is wasted without further processing of the waste, it can cause disturbances in the environmental balance as the environment will not function as before in terms of health, welfare and biological safety [2].

The scallop shell itself is a raw material for producing high chitin and chitosan, with the amount of chitin content in the shell itself ranging from $14-35 \%$ [3]. Chitin is a class of carbohydrates that can be produced from marine waste, or commonly called biopolymers that 
contain the most nitrogen $(\mathrm{N})$ in nature. The high value of $\mathrm{N}$ in this polymer makes chitin and chitosan much in demand by industry. By definition, chitosan is chitin that has been deacylated and leaves no more than $40-45 \%$ acetyl groups [4].Isolation of scallop shells goes through 3 process stages including the Deproteination Process (Protein Removal Process on Scallop Shells), Demineralization Process (Mineral Removal Process on Scallop Shells), Deacetylation Process (Process to remove acetyl groups with a strong alkaline solution). The quality of chitosan can be seen from the value of the degree of deacetylation. The degree of deacetylation affects the quality of a chitosan, because it is used to determine the charge of the free amine group and is used to distinguish between chitin and chitosan [5].

\section{METHODS}

a. Material and Tools

The materials used in this research were Scallop Shells, Sodium Hydroxide $(\mathrm{NaOH})$, Hydrochloric Acid $(\mathrm{HCl})$ and distilled water. Chitosan characterization was tested using UV-Vis Spectrophotometer.

b. Procedure

1) Scallop shell preparation. The scallop shell (Placuna placenta) was cleaned using a brush until the meat attached to the shell was removed then rinsed with water until clean. The clean shells were dried in the sun for 1 day. The dried clam shell were mashed using grinding machine to obtain the scallop shell powder and then shieved with 200 mesh sized. The powder obtained was ready for next process.

2) Deproteination process. The powder that had been weighed as much as 40 grams was dissolved with $5 \mathrm{M} \mathrm{NaOH}$ in a ratio of $1: 10(\mathrm{w} / \mathrm{v})$. After that, the sample was put into the extractor tube and stirred using magnetic stirrer at $250 \mathrm{rpm}$ with heating at $1000 \mathrm{C}$ for 2 hours. Sample was cooled and then filtered to obtain chitin less protein and neutralized using distilled water until $\mathrm{pH}$ was neutral. Deproteinized solids were continued with demineralization process.

3) Demineralization process. The powder obtained before had been weighed as much as 30 grams was dissolved with $0.6 \mathrm{M} \mathrm{HCl}$ with a ratio of $1: 15(\mathrm{w} / \mathrm{v})$. After that, the sample was put into the extractor tube and stirred using magnetic stirrer at $200 \mathrm{rpm}$ with heating temperature of $500 \mathrm{C}$ for 30 minutes. The results of process were filtered, the residue was taken and washed using distilled water until the resulting $\mathrm{pH}$ was neutral and continued with drying process in the oven at $1200 \mathrm{C}$ for 1 hour.

4) Deacetylation process. 20 grams of chitin were weighed and certain concentration of $\mathrm{NaOH}$ solution was added in a ratio of 1:20 (w/v). Concentration of $\mathrm{NaOH}$ solution was independent variable with a value of 50\% - 70\% (w/v). After that, the sample was put into the extraction tube and stirred using magnetic stirrer with stirring speed at $300 \mathrm{rpm}$ with heating temperature for 2 hours. Heating temperature was indepent variable too with a value of $7500 \mathrm{C}-1250 \mathrm{C}$. The results obtained were filtered and washed with distilled water until $\mathrm{pH}$ was neutral. To obtain chitosan product, it was dried in oven at temperature $1200 \mathrm{C}$ for 1 hour.

5) Chitosan characterization. Amount of $40 \mathrm{mg}$ of chitosan that had been produced was dissolved in $50 \mathrm{~mL}$ of $0.2 \mathrm{M} \mathrm{HCl}$ solution and the absorbance was readed using UV-Vis spectrophotometer at wavelength of $200 \mathrm{~nm}$. 


\section{RESULT AND DISCUSSION}

The deproteination process was carried out at 3 different concentrations of $\mathrm{NaOH}$, namely $50 \%, 60 \%$, and $70 \%$. The concentration of $\mathrm{NaOH}$ used in mass / volume. The results of the research on these 3 conditions are shown in Figure 1.

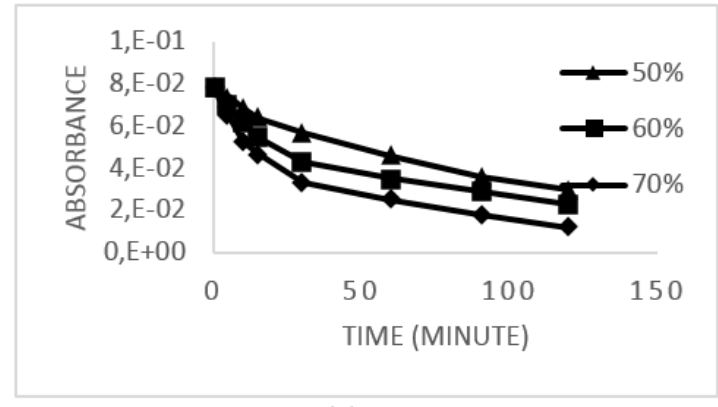

(a)

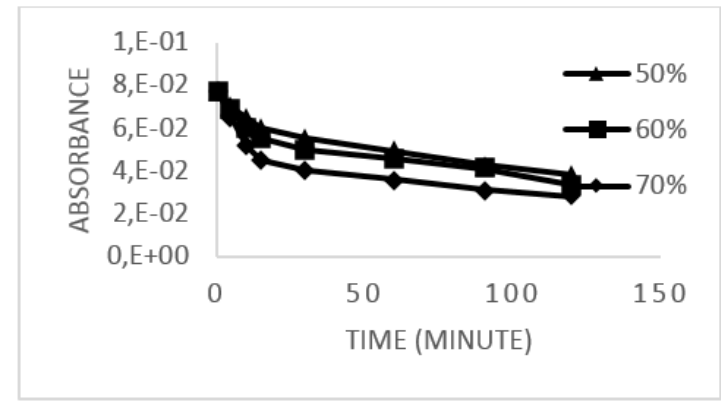

(b)

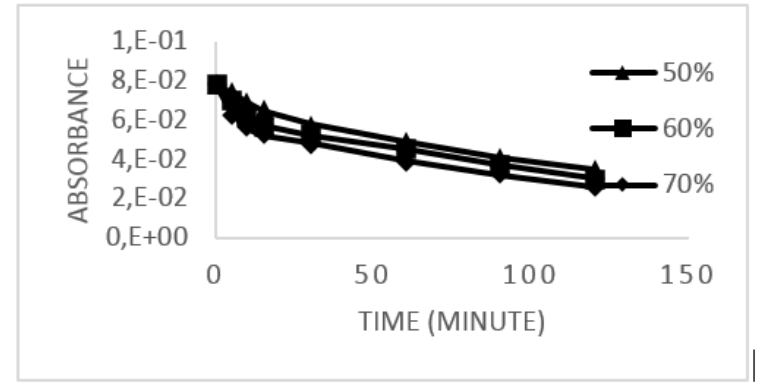

(c)

Figure 1. Absorbance of acetyl groups with various concentrations of $\mathrm{NaOH}$ solution at (a) $75^{\circ} \mathrm{C}$; (b) $100^{\circ} \mathrm{C}$; (c) $125^{\circ} \mathrm{C}$ heating temperature process.

The absorbance can be analogous to the acetyl group attached to chitosan. However, the absorbance value cannot be directly used to indicate the number of acetyl groups contained in chitosan. It is necessary to carry out the process of making a calibration curve further to be able to determine the acetyl group contained in chitosan so that later the value of the degree of deacetylation can be searched.

Based on the absorbance value, changes in the concentration value of the $\mathrm{NaOH}$ solution used gave a uniform pattern. The higher the concentration value of the $\mathrm{NaOH}$ solution used, the better the process of removing the acetyl group from chitosan. This can happen because the acetyl group will undergo a substitution reaction with the $\mathrm{OH}$-group on the base. The more $\mathrm{OH}$ - groups provided, the higher possibility for a substitution reaction to occur, resulting in a better deacetylation process. This phenomenon occurs at various temperatures indicating that it occurs uniformly. This is also supported by Danarto's research that treatment with higher concentrations will result in better removal of acetyl groups in the process of making chitosan from green mussel shells [6].

On the other hand, this study also uses heating temperature as an independent variable. The temperatures used in this study were $750 \mathrm{C}, 1000 \mathrm{C}$, and $1250 \mathrm{C}$. The results of the study are shown in Figure 2. 


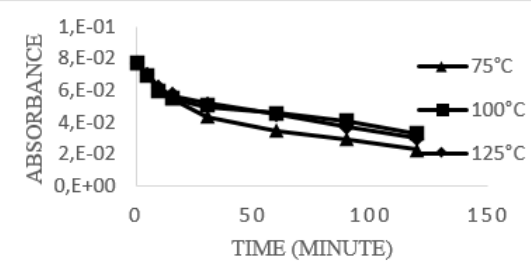

(a)

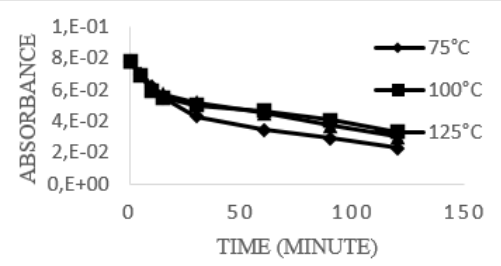

(b)

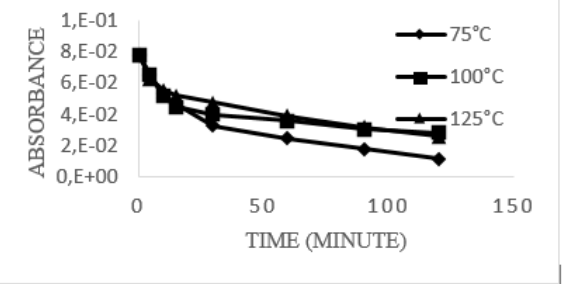

(c)

Figure 2. Absorbance of acetyl groups with various heating temperature process at (a) $50 \%$; (b) $60 \%$; (c) $70 \%$ concentration of $\mathrm{NaOH}$ solution.

Different phenomena occur in changes in heating temperature. This variable does not form a unique pattern. Subjective observation becomes a way of making decisions. In this variable, the optimum result was obtained at a temperature of 750C. This can be observed from the difference in absorbance values between the unprocessed acetyl group content and after being processed for 2 hours. With increasing heating temperature, the difference obtained decreases, both at $1000 \mathrm{C}$ and $1250 \mathrm{C}$. The difference in values at temperatures of $1000 \mathrm{C}$ and $1250 \mathrm{C}$ is not large so it can be considered as a deviation value and gives similar results. However, further research needs to be done on the effect of heating temperature due to deviations in the phenomenon which should follow Arrhenius law.

Based on all the data obtained, the processing time for 2 hours is considered appropriate because the process is still going on for 2 hours but the reaction speed has slowed down causing the running reaction to be no longer effective. According to Danarto's research, a long time but low concentration will give no better results than a relatively short time with high concentration[6].

\section{CONCLUSIONS AND SUGGESTIONS}

The optimum conditions for the deacetylation process were obtained at a heating temperature of $750 \mathrm{C}$ and a concentration of $70 \% \mathrm{NaOH}$ solution for 2 hours. This condition results in the most loss of acetyl groups.

\section{REFERENCES}

[1] Tribawono, D., 2013, Hukum Perikanan Indonesia, PT. Citra Aditya Bakti, Bandung, Indonesia

[2] Kusuma, E. W., 2012, Pemanfaatan Limbah Kulit Kerang Sebagai Bahan Campuran Paving Block, Skripsi Program Studi Teknik Lingkungan, Fakultas Teknik Sipil dan Perencanaan, Universitas Pembangunan Nasional Veteran Jawa Timur. Surabaya, Indonesia 
UMGCINMATIC : $\mathbf{1}^{\text {st }}$ Rethinking Education during Covid-19 Era: Challange and Innovation Volume 1 No 2

[3] Sinardi, 2013. Pembuatan Karakterisasi dan Aplikasi Kitosan dari Cangkang Kerang Hijau (Mytuls Virdis Linneaus) Sebagai Koagulan Pejernih Air. Konferensi Nasional Teknologi Sipil, 7 : 33-38.

[4] Dewi, I.S., Alamsjah, M.A., and Sugijanto, N.E.N., 2016, Isolasi dan Karakteristik Kitosan dari Cangkang Ranjungan (Portunus Pelagicus), Jurnal Biosains Pascasarjana Vol. 18. Sekolah Pascasarjana Universitas Airlangga, Indonesia

[5] Mastuti, W., 2005, Pengaruh Konsentrasi NaOH dan Suhu pada Proses Deasetilasi Khitin dari Kulit Udang, Jurnal Teknik Kimia. 4(1). Pp. 21-25 